\title{
Academic capitalism and the entrepreneurial university: some perspectives from the Americas
}

\author{
Capitalismo acadêmico e universidade empresarial: algumas perspectivas \\ das Américas
}

\section{El capitalismo académico y la universidad empresarial: algunas perspectivas de las Américas}

\begin{abstract}
Patrícia Somers ${ }^{1}$
Universidade do Texas em Austin, professora associada no Departamento de Liderança e Política
\end{abstract}

\section{Cory Davis ${ }^{2}$}

Universidade do Texas em Austin, Senior Grants Specialist

\section{Jessica Fry ${ }^{3}$}

Universidade do Texas em Austin, assistente de pesquisa

\begin{abstract}
Lisa Jasinski ${ }^{4}$
Universidade Trinity, Assistente Especial do Vice-Presidente de Assuntos Acadêmicos
\end{abstract}

\section{Elida Lee ${ }^{5}$}

Universidade do Texas em Austin, Diretora de Eficácia da Organização

\begin{abstract}
Since the Worldwide Financial Crisis of 2008, higher education institutions around the world have been forced to change their financial practices to focus on the bottom line. One such approach is academic capitalism, the heart of which is the entrepreneurial university which views faculty members as producers of capital (not educators), students as consumers (not learners), and business/industry, accreditors, and NGOs as valued business partners. This article defines academic capitalism,

Doutora pela Universidade de New Orleans; Mestre em Artes pela Universidade de Illinois.

2 Mestre em Artes pela Universidade de San Francisco; doutoranda no Programa de Liderança em Ensino Superior da Universidade do Texas em Austin.

3 Doutora pelo Programa de Programa de Liderança em Ensino Superior da Universidade do Texas em Austin; Mestre de Artes, Educação pela Universidade de Pennsylvania.

4 Doutora pelo Programa de Liderança em Ensino Superior da Universidade do Texas em Austin; Mestre de Artes pela Universidade do Wisconin.

5 Doutora em Administração de Ensino Superior pela Universidade do Texas em Austin; Mestre em Educação, Currículo e Instrução pela Universidade do Texas em Austin.
\end{abstract}


reviews the research literature, presents perspectives of academic capitalism in the Americas and discusses the implications of academic capitalism for Latin America. The article ends using anthropophagi to assess what is useful about academic capitalism for Brazil.

Keywords: Academic capitalism. Entrepreneurial universities. Higher education.

Resumo: Desde a Crise Financeira Mundial de 2008, as instituições de ensino superior em todo o mundo foram forçadas a mudar suas práticas financeiras para se concentrar em fatores não acadêmicos, o que foi chamado de capitalismo acadêmico. No centro do capitalismo acadêmico está a universidade empresarial, que considera os professores como produtores de capital (não educadores), estudantes como consumidores (não aprendizes) e empresas/indústria, credenciadores e ONGs como valiosos parceiros de negócios. Neste artigo define-se capitalismo acadêmico, revisa-se a literatura de pesquisa, discutem-se perspectivas do capitalismo acadêmico das Americas e discutem-se as implicações do capitalismo acadêmico para a América Latina. No artigo finaliza-se com o uso da antropofagia para avaliar o que é útil sobre o capitalismo acadêmico para o Brasil.

Palavras-chave: Capitalismo acadêmico. Universidades empresariais. Educação superior.

Resumen: Desde la Crisis Financiera Mundial de 2008, las instituciones de educación superior de todo el mundo se han visto obligadas a cambiar sus prácticas financieras para centrarse en la línea de fondo no académicos, que se llama capitalismo académico. En el corazón del capitalismo académico está la universidad emprendedora, que considera a los profesores como productores de capital (no educadores), estudiantes como consumidores (no aprendices), y negocios / industria, acreditadores y ONGs como valiosos socios de negocios. Este artículo define el capitalismo académico, revisa la literatura de investigación, discute perspectivas del capitalismo académico en las Américas y discute las implicaciones del capitalismo académico para América Latina. El artículo termina utilizando antropofagia para evaluar lo que es útil sobre el capitalismo académico para Brasil.

Palabras clave: Capitalismo Académico. Universidades Empresariales. Educación Superior. 


\section{INTRODUCTION}

One criticism of higher education in the United States is its spiraling cost of higher education. With public subsidies at low levels, the average tuition at a public 4-year university is $\$ 3,980$ USD/year (COLLEGE BOARD, 2015). Contrasted with that figure is $\$ 56,000$ USD for total cost (tuition + books + living expenses) at the most expensive private university. As a result, the debate on how to reduce costs for students and their families focuses on the twin objectives of reducing costs and obtaining new revenue in the form of patents, grants, contracts, gifts from corporations and individuals, fees for services, and other entrepreneurial activities. Collectively, these activities are labelled academic capitalism, a term developed by Slaughter and Rhoades (2009). They define academic capitalism as "the pursuit of market and market-like activities to generate external revenue." With the emphasis on generating revenue, academic capitalism forces universities to become more entrepreneurial and corporate; thus the term entrepreneurial university. In the entrepreneurial university, the emphasis is on generating income and cutting costs. Faculty, staff, and administrators who excel with this approach are rewarded.

The move to the entrepreneurial university has been the trend in higher education institutions in Brazil, and in Latin America in general. Globalization, with the prioritization of the Knowledge Society, and with the focus on the development of high level human resources, focuses on universities. In Brazil, the 1996 legislation provides for flexible higher education institutions in all sectors and supports an expansion of the higher education system, especially in the private for-profit sector.

This article reports mainly the literature on academic capitalism and presents, perspectives, data and examples of academic capitalism from the Americas, and discusses the implications of academic capitalism for Latin American universities. We end with a discussion of academic capitalism in Brazil.

\section{REVIEW OF LITERATURE}

Much has been written about universities operating within a contemporary neoliberal economic framework, including the specific rise of what Slaughter and Leslie (1997, p. 6) termed the "academic capitalist knowledge-learning regime." Slaughter and Leslie argued that universities behave like businesses in the commercial 
marketplace and the influence of market forces on post-secondary education is stronger than ever before. Slaughter and Leslie mark the beginning of academic capitalism as the effect of the neoliberal ideology of President Ronald Reagan in the U.S. of the 1980s. Reagan's neoliberal state was, first and foremost, concerned with advancing the interests of select large corporations and private individuals, rather than the greater good of society (BALTODANO, 2012), breaking with the philosophy of education as a public good to benefit all citizens. Neoliberal policies promote privatization, industrial deregulation, commercialization, accountability for public agencies, and seek to promote the so-called "new knowledge economy" (SLAUGHTER; RHOADES, 2009). Within a neoliberal context, higher education has been transformed effectively from a public good to a commodity that can be sold to benefit the narrow interests of wealthy individuals and corporations. The 2008 global recession amplified critiques concerning college affordability (SLAUGHTER; RHOADES, 2016), reinforcing the belief that post-secondary education is a costly private good.

Rather than a single policy or trend, academic capitalism is a framework implemented by a network of actors through federal and state governmental policies, public attitudes, and university practices. Academic capitalism affects nearly every part of a university and every stakeholder - including students, faculty members, administrators, university advisors, and society at large. We maintain that these changes have caused many negative effects.

One indication of the trend is the rapid rise of educational costs for students and their families (SPELLINGS, 2006). A significant reduction in public support for higher education is the leading cause for this increase (PRIEST; ST. JOHN, 2006; WINSTON, 1997, p. 279). Also contributing to rising costs, Slaughter and Rhoades (2004, p. 279) argued that universities have not done enough to reduce expenses, as they initiate market/market-like strategies to "exploit the commercial potential of students" and have profited from an increase in non-instructional auxiliary services. Prior to the 1980s, in the United States, many poor and middle-income students benefitted from federal and state grant aid to pay for college; now these programs have been replaced by loan programs which require students accrue considerable debt to finance their education (SELINGO, 2015). In the book Academically Adrift, Arum and Roska (2010) argued that decades of rising educational costs have not led to gains in student learning. Taken together, the net effect of academic capitalism is a more expensive and lower quality education. 
Faculty members and researchers are another population negatively influenced by the neoliberal academic capitalist regime. The face of the faculty has changed significantly; for example, the number of part-time and adjunct faculty has increased while the number of tenured positions has declined (AMERICAN ASSOCIATION OF UNIVERSITY PROFESSORS, 2014). Across the United States, faculty members have had limited wage growth and faculty unions have reduced bargaining power(DONOGHUE, 2008; SLAUGHTER; LESLIE, 1997). Concurrently, the number of highly-paid administrators and administrative professionals, called “administrative bloat" have increased (BOK, 2002; CHACE, 2013). The lasting effect of these shifts in the workforce is an erosion of shared governance and increasing tension between faculty and administrators (BOWEN; TOBIN, 2015; GERBER, 2014; GINSBERG, 2013; GONZALES, 2012). Graduate student funding has also been negatively influenced and many graduate students face increasingly limited prospects to secure full-time employment in the professoriate.

While the faculty workforce has been negatively influenced by academic capitalism, the secondary consequences to society are even more severe. Academic capitalism threatens the core tenets of academic freedom - a founding principle that ensured an investment in pure research to advance the interests of society. The total investment in federal grants to promote scientific research remained stagnant since the 1980s (SLAUGHTER; RHOADES, 2004). The line has been blurred between the university campus and the marketplace. Faculty members must compete with one another for limited research funding and often, research projects with commercial potential are more likely to receive funding. Within the prevailing academic capitalist framework, support for faculty research has been diverted away from the arts and humanities and toward science and technology disciplines where breakthrough discoveries can be patented and sold (SLAUGHTER; RHOADES, 2004). Many business leaders now serve on the governing boards of private universities where they advise administrators and promote policies to further advantage their commercial interests (SLAUGHTER; RHOADES, 2016). Due to the changes in research funding, universities no longer operate as independent agencies to promote the social good - faculty members must adapt their research agendas according to the priorities of granting agencies and large corporations.

As Slaughter and Leslie (1997, p. 6) warned, the political and economic changes that enabled the growth of academic capitalism are "global and structural; 
they are not likely to disappear and allow us to return to business as usual." Whereas it is unlikely that the damage will ever be fully reversed, we argue that public reinvestment in higher education may be a first step in beginning to curb this harmful trend. By shining a light on data on research and teaching at one public research university in the United States, we seek to bring awareness and ultimately action to these troubling concerns.

One particularly troubling organizational tool used by academic capitalists is disruptive innovation, which uses technology to restructure entire industries and decrease costs dramatically to enroll new student-customers. For example, online university courses appeal to many students due to the perception of being a more convenient, less rigorous, and less expensive alternative to traditional education. In the United States, Massive Open Online Courses (MOOCs) and online-only institutions, many of which are for-profit, have emerged to fill the gap left by traditional colleges and universities by serving non-traditional or low-income students. Christensen and Eyring (2011, p. 47) asserted that disruptive innovation is making "a complicated and expensive product [in this case, a college education] simpler and cheaper" in order to attract a "new set of customers."

Originally, Christensen and Eyring (2011) defined "disruptive innovation" as a technology-based theory for the business world; however, they have since applied it to education. According to this theory, disruptive innovation has the potential to take over an existing industry such as higher education. Christensen believes institutions like the University of Phoenix will be "the leader of tomorrow", while half of the traditional colleges in the United States could face bankruptcy in 15 years (GOLDSTEIN, 2015, p. 2). Lepore (2014) insists Christensen's theory, which originated in the computer disk-drive industry, is historically flawed and should not be applied to colleges and universities.

Using Harvard University as the example for The Innovative University, Christensen and Eyring (2011) asserted that the modern university should include a mix of face-to-face and online learning. Institutions failing to disrupt this way will inevitably face hardships, while those that "marry the benefits of the on-campus experience and online learning" will experience growth "beyond what they imagined" (CHRISTENSEN; EYRING, 2011, p. 51). This is done by making drastic philosophical changes that attack centuries of educational tradition, such as cutting down on fulltime, tenured faculty members and employing contingent faculty willing to commit 
to faster and cheaper degree offerings; establishing "heavyweight innovation teams"; and cutting back on the number of graduate programs offered, and offering "no frills" four-year university degrees for \$10,000 USD (LEPORE, 2014; CHRISTENSEN; EYRING, 2011).

While Lepore (2014) argues that this type of system pertains more to business start-up companies and not universities, the strategy of disruptive innovation has been adopted by many prestigious research universities, because some leaders argue that higher education should be held to the same standards as other industries those that do not innovate and disrupt will cease to exist (SELINGO, 2012).

Supporters of Christensen and disruptive innovation believe online degrees and other cost-cutting methods will reinvent higher education, but empirical research has yet to back up this theory. The next section of this article presents a case study of a research university that employs a strategy of innovative disruption by hiring cheaper academic professionals to replace tenured faculty members and reduce costs.

\section{ACADEMIC CAPITALISM AND THE RESEARCH UNIVERSITY}

In the U.S., faculty salaries account for just under $17 \%$ of a university's budget (IPEDS, 2015). Academic capitalism suggests that some faculty work can be accomplished by much cheaper academic professionals who do not have the salaries, academic freedom, and other job protections of the faculty. In the U.S. the "other professional" category (i.e., academic professionals) is the fastest growing job title in universities (SNYDER; DILLOW, 2011). In fall of 2011, nearly 25\% of employees at the most prestigious and productive Research Intensive $(\mathrm{R} 1)^{6}$ universities in the U.S. were categorized as other professionals (Table 1). Since the 1970s, full-time faculty positions at American universities decreased by $26 \%$ and full-time tenuretrack positions dropped by 50\%. Further, full-time, non-tenure track faculty jobs increased by $62 \%$, with a $76 \%$ increase in part-time instructional staff. Fully $70 \%$ of

\footnotetext{
${ }^{6}$ The Carnegie Classification ${ }^{T M}$ is the framework for recognizing and describing institutional type in U.S. higher education. The category doctoral universities includes institutions that awarded at least 20 research/ scholarship doctoral degrees during the current year. Doctoral universities are further defined by their research productivity - R1: Doctoral Universities have the highest research activity; R2: Doctoral Universities have a higher research activity; and R3: Doctoral Universities have a moderate research activity. The scheme also has categories for Master's colleges and universities, liberal arts colleges, community colleges, specialty schools and tribal (Native American) colleges.
} 
all employees who teach in American universities are now off the tenure track and part time (AMERICAN ASSOCIATION OF UNIVERSITY PROFESSORS, 2014).

Table 1 - R1 universities in fall 2011, by percent of academic professionals

\begin{tabular}{|c|c|c|c|}
\hline Research 1 Institution & Total Employees & Other Professionals & Percent \\
\hline Arizona State University-Tempe & 12006 & 3732 & $31.08 \%$ \\
\hline Boston College & 4601 & 866 & $18.82 \%$ \\
\hline Boston University & 12213 & 2211 & $18.10 \%$ \\
\hline Brandeis University & 2289 & 520 & $22.72 \%$ \\
\hline Brown University & 4870 & 988 & $20.29 \%$ \\
\hline California Institute of Technology & 3989 & 1095 & $27.45 \%$ \\
\hline Carnegie Mellon University & 7577 & 1850 & $24.42 \%$ \\
\hline Case Western Reserve University & 5705 & 1841 & $32.27 \%$ \\
\hline Clemson University & 6282 & 1528 & $24.32 \%$ \\
\hline Colorado State University-Fort Collins & 9593 & 2684 & $27.98 \%$ \\
\hline $\begin{array}{l}\text { Columbia University in the City of } \\
\text { New York }\end{array}$ & 19324 & 3805 & $19.69 \%$ \\
\hline Cornell University & 12873 & 2548 & $19.79 \%$ \\
\hline $\begin{array}{l}\text { CUNY Graduate School and University } \\
\text { Center }\end{array}$ & 2299 & 295 & $12.83 \%$ \\
\hline Duke University & 18976 & 7087 & $37.35 \%$ \\
\hline Emory University & 11994 & 4519 & $37.68 \%$ \\
\hline Florida International University & 5954 & 1431 & $24.03 \%$ \\
\hline Florida State University & 9580 & 2198 & $22.94 \%$ \\
\hline George Mason University & 6032 & 971 & $16.10 \%$ \\
\hline George Washington University & 6827 & 2535 & $37.13 \%$ \\
\hline Georgetown University & 6518 & 1104 & $16.94 \%$ \\
\hline $\begin{array}{l}\text { Georgia Institute of Technology-Main } \\
\text { Campus }\end{array}$ & 10526 & 4121 & $39.15 \%$ \\
\hline Georgia State University & 6402 & 1278 & $19.96 \%$ \\
\hline Harvard University & 18969 & 4271 & $22.52 \%$ \\
\hline Indiana University-Bloomington & 11473 & 2664 & $23.22 \%$ \\
\hline Iowa State University & 8586 & 2037 & $23.72 \%$ \\
\hline Johns Hopkins University & 21119 & 7102 & $33.63 \%$ \\
\hline Kansas State University & 6357 & 1819 & $28.61 \%$ \\
\hline Louisiana State University & 8855 & 2639 & $29.80 \%$ \\
\hline Massachusetts Institute of Technology & 14570 & 2341 & $16.07 \%$ \\
\hline Michigan State University & 14404 & 4975 & $34.54 \%$ \\
\hline New York University & 18643 & 3225 & $17.30 \%$ \\
\hline
\end{tabular}




\begin{tabular}{|c|c|c|c|}
\hline Research 1 Institution & Total Employees & Other Professionals & Percent \\
\hline $\begin{array}{l}\text { North Carolina State University at } \\
\text { Raleigh }\end{array}$ & 11627 & 3281 & $28.22 \%$ \\
\hline Northeastern University & 5616 & 1428 & $25.43 \%$ \\
\hline Northwestern University & 9629 & 3104 & $32.24 \%$ \\
\hline Ohio State University-Main Campus & 30643 & 11522 & $37.60 \%$ \\
\hline Oregon State University & 6397 & 1193 & $18.65 \%$ \\
\hline $\begin{array}{l}\text { Pennsylvania State University-Main } \\
\text { Campus }\end{array}$ & 18126 & 4015 & $22.15 \%$ \\
\hline Princeton University & 6788 & 2117 & $31.19 \%$ \\
\hline Purdue University-Main Campus & 15163 & 2529 & $16.68 \%$ \\
\hline Rice University & 2963 & 716 & $24.16 \%$ \\
\hline Rutgers University-New Brunswick & 11235 & 3085 & $27.46 \%$ \\
\hline Stanford University & 16653 & 4350 & $26.12 \%$ \\
\hline Stony Brook University & 5561 & 1186 & $21.33 \%$ \\
\hline SUNY at Albany & 3554 & 858 & $24.14 \%$ \\
\hline Syracuse University & 6546 & 962 & $14.70 \%$ \\
\hline Temple University & 9109 & 2069 & $22.71 \%$ \\
\hline $\begin{array}{l}\text { Texas A \& M University-College } \\
\text { Station }\end{array}$ & 10866 & 2765 & $25.45 \%$ \\
\hline Texas Tech University & 6557 & 879 & $13.41 \%$ \\
\hline The University of Tennessee-Knoxville & 15520 & 2602 & $16.77 \%$ \\
\hline The University of Texas at Arlington & 5697 & 558 & $9.79 \%$ \\
\hline The University of Texas at Austin & 24765 & 4688 & $18.93 \%$ \\
\hline The University of Texas at Dallas & 4253 & 971 & $22.83 \%$ \\
\hline Tufts University & 5791 & 1462 & $25.25 \%$ \\
\hline Tulane University of Louisiana & 5338 & 488 & $9.14 \%$ \\
\hline University at Buffalo & 6294 & 1513 & $24.04 \%$ \\
\hline University of Alabama at Birmingham & 9761 & 3388 & $34.71 \%$ \\
\hline University of Arizona & 15161 & 5407 & $35.66 \%$ \\
\hline University of Arkansas & 6032 & 1666 & $27.62 \%$ \\
\hline University of California-Berkeley & 15957 & 4259 & $26.69 \%$ \\
\hline University of California-Davis & 16167 & 3821 & $23.63 \%$ \\
\hline University of California-Irvine & 9965 & 2371 & $23.79 \%$ \\
\hline University of California-Los Angeles & 22803 & 6802 & $29.83 \%$ \\
\hline University of California-Riverside & 5223 & 1094 & $20.95 \%$ \\
\hline University of California-San Diego & 15873 & 4702 & $29.62 \%$ \\
\hline University of California-Santa Barbara & 6417 & 1403 & $21.86 \%$ \\
\hline
\end{tabular}




\begin{tabular}{|c|c|c|c|}
\hline Research 1 Institution & Total Employees & Other Professionals & Percent \\
\hline University of California-Santa Cruz & 4888 & 1229 & $25.14 \%$ \\
\hline University of Central Florida & 6822 & 1501 & $22.00 \%$ \\
\hline University of Chicago & 11478 & 3715 & $32.37 \%$ \\
\hline University of Cincinnati-Main Campus & 9436 & 1978 & $20.96 \%$ \\
\hline University of Colorado Boulder & 9818 & 924 & $9.41 \%$ \\
\hline University of Connecticut & 11519 & 4321 & $37.51 \%$ \\
\hline University of Delaware & 5820 & 1255 & $21.56 \%$ \\
\hline University of Florida & 18070 & 3528 & $19.52 \%$ \\
\hline University of Georgia & 13236 & 3839 & $29.00 \%$ \\
\hline University of Hawaii at Manoa & 6150 & 1613 & $26.23 \%$ \\
\hline University of Houston & 6761 & 2079 & $30.75 \%$ \\
\hline University of Illinois at Chicago & 15282 & 5715 & $37.40 \%$ \\
\hline $\begin{array}{l}\text { University of Illinois at Urbana-Cham- } \\
\text { paign }\end{array}$ & 16436 & 3273 & $19.91 \%$ \\
\hline University of Iowa & 13060 & 4706 & $36.03 \%$ \\
\hline University of Kansas & 10261 & 2784 & $27.13 \%$ \\
\hline University of Kentucky & 13627 & 3194 & $23.44 \%$ \\
\hline University of Louisville & 7924 & 2482 & $31.32 \%$ \\
\hline University of Maryland-College Park & 13451 & 2661 & $19.78 \%$ \\
\hline University of Massachusetts-Amherst & 7975 & 1376 & $17.25 \%$ \\
\hline University of Miami & 11697 & 1392 & $11.90 \%$ \\
\hline University of Michigan-Ann Arbor & 24674 & 7603 & $30.81 \%$ \\
\hline University of Minnesota-Twin Cities & 22608 & 4308 & $19.06 \%$ \\
\hline University of Mississippi & 3878 & 881 & $22.72 \%$ \\
\hline University of Missouri-Columbia & 19681 & 4297 & $21.83 \%$ \\
\hline University of Nebraska-Lincoln & 8423 & 1902 & $22.58 \%$ \\
\hline $\begin{array}{l}\text { University of New Mexico-Main } \\
\text { Campus }\end{array}$ & 10156 & 2621 & $25.81 \%$ \\
\hline $\begin{array}{l}\text { University of North Carolina at Chapel } \\
\text { Hill }\end{array}$ & 15472 & 4514 & $29.18 \%$ \\
\hline University of North Texas & 5525 & 978 & $17.70 \%$ \\
\hline University of Notre Dame & 6634 & 1901 & $28.66 \%$ \\
\hline $\begin{array}{l}\text { University of Oklahoma-Norman } \\
\text { Campus }\end{array}$ & 7508 & 1785 & $23.77 \%$ \\
\hline University of Oregon & 6074 & 1201 & $19.77 \%$ \\
\hline University of Pennsylvania & 16771 & 4668 & $27.83 \%$ \\
\hline $\begin{array}{l}\text { University of Pittsburgh-Pittsburgh } \\
\text { Campus }\end{array}$ & 14928 & 4716 & $31.59 \%$ \\
\hline
\end{tabular}




\begin{tabular}{|c|c|c|c|}
\hline Research 1 Institution & Total Employees & Other Professionals & Percent \\
\hline University of Rochester & 10133 & 1772 & $17.49 \%$ \\
\hline University of South Carolina-Columbia & 8542 & 2907 & $34.03 \%$ \\
\hline $\begin{array}{l}\text { University of South Florida-Main } \\
\text { Campus }\end{array}$ & 7778 & 1786 & $22.96 \%$ \\
\hline University of Southern California & 19144 & 6060 & $31.65 \%$ \\
\hline University of Utah & 11114 & 2954 & $26.58 \%$ \\
\hline University of Virginia-Main Campus & 10169 & 2630 & $25.86 \%$ \\
\hline $\begin{array}{l}\text { University of Washington-Seattle } \\
\text { Campus }\end{array}$ & 21755 & 9665 & $44.43 \%$ \\
\hline University of Wisconsin-Madison & 21154 & 7478 & $35.35 \%$ \\
\hline University of Wisconsin-Milwaukee & 4992 & 1204 & $24.12 \%$ \\
\hline Vanderbilt University & 24982 & 8065 & $32.28 \%$ \\
\hline Virginia Commonwealth University & 7511 & 897 & $11.94 \%$ \\
\hline $\begin{array}{l}\text { Virginia Polytechnic Institute \& State } \\
\text { University }\end{array}$ & 10275 & 1880 & $18.30 \%$ \\
\hline Washington State University & 7371 & 1730 & $23.47 \%$ \\
\hline Washington University in St Louis & 13964 & 2924 & $20.94 \%$ \\
\hline Wayne State University & 7782 & 2627 & $33.76 \%$ \\
\hline West Virginia University & 8373 & 1647 & $19.67 \%$ \\
\hline Yale University & 15789 & 2221 & $14.07 \%$ \\
\hline Average & & & $24.78 \%$ \\
\hline
\end{tabular}

Source: Integrated Postsecondary Education Data System (2018).

The Integrated Postsecondary Education Data System (IPEDS), the national data system for universities in the U.S., identifies eight classifications of employees: 1) executive, administrative, and managerial, 2) faculty (instructional/research/public service), 3) instruction/research assistants, 4) other professionals (support/service), 5) technical staff and paraprofessionals, 6) clerical and secretarial staff, 7) skilled crafts persons, and 8) service/maintenance. Other professionals (support/service) are defined as "staff employed for the primary purpose of performing academic support, student service, and institutional support, whose assignments would require either a baccalaureate degree or higher or experience of such kind and amount as to provide a comparable background." (INTEGRATED POSTSECONDARY EDUCATION DATA SYSTEM, 2015). These jobs include computer software engineers, counselors, academic support specialists, business operations specialists, human resources, 
convention planners, financial analysts, database administrators, health educators, directors, librarians, therapists, and registered nurses, among many other job titles.

Lee, Somers and Fry (2016) investigated the duties of other professionals at a research university (for purposes of the study called Entrepreneurial Research University or ERU) in the U.S. They surveyed 1,036 non-faculty professionals to determine their involvement in three areas of core faculty work: research, teaching, and public service. This included faculty-like work such as publishing in peer-reviewed journals, applying for grants, designing curricula, sitting on committees, and collaborating with industry. Of the 759 respondents, $78 \%$ participated in at least one of the three elements of faculty work. Forty percent reported involvement in teaching, 40\% in research, and $47 \%$ in public service. The majority of other professionals who participated in teaching or public service as part of their employment said that these duties accounted for less than $25 \%$ of their time. Other professionals who participated in research reported this being either less than $25 \%$ or more than $80 \%$ of their job duties.

The study found that a large number of professionals at ERU were directly participating in the production of research, teaching, and/or public service. Their duties were less supportive or administrative and more aligned with faculty-like work, particularly with research and public service. These results described the duties and roles of the fast growing job category of other professionals at research universities. To meet the demands of academic capitalism and the morphing mission of universities, other professionals are recruited to supplement the core missions of the university through faculty-like job duties, replacing full-time tenured faculty.

The ultimate irony of the Lee, Somers, and Fry (2016) research is that it demonstrates the destructive effect of academic capitalism on the elite R-1 institutions. Since R-1s are the vaunted model on which various world-wide rankings are founded, other types of universities are forced to adapt market-like behaviors in the wild hope of reaching the top of the rankings. On the other hand, these non-R1 institutions have generally fewer resources, missions that focus on teaching and public service, and a different mix of students. While marketization harms the academic and public service spirit of R-1 universities, it can overextend or bankrupt other types of institutions. 


\section{APPLICATION TO LATIN AMERICAN UNIVERSITIES}

From the data presented in this article, it is clear that the expansion and internationalization of higher education in the U.S. are accompanied by marketization of the academy. Internal and external forces have pushed Latin American universities, regardless of their mission, toward marketization as well. At private universities and many public universities, these students pay tuition and take out student loans to pay educational costs. In order to propel Latin American universities to the top of the world rankings, additional funds are needed regularly to modernize facilities, purchase new technologies, and hire "superstar" faculty members. This "academic arms race" to climb the ladder of international rankings is costly and has high stakes for Latin American universities, often resulting in choices that only satisfy the "neoliberal" ranking metrics instead of other domestic or regional development priorities (ORDORIKA; LLOYD, 2015, p. 387). Universities that fall short in the international rankings, regardless of their mission or metrics, are viewed critically by governments, the public and the media. Thus, university/industry partnerships, technology/patent transfers, and government/NGO grants and contracts, and other means of bringing in new revenue are required. When accompanied by a corresponding decrease in funding for instruction, universities must hire itinerant faculty members and charge tuition to meet the full cost of instruction.

This academic capitalism by accretion and subtraction is prevalent in higher education in the U.S. However, the implications are different for institutions in Latin America. Universities in both regions face similar challenges: decreasing funding, mission creep, and the pressure to compete internationally with the top research universities (BERNASCONI, 2008). However, while there are exceptions, in general Latin American universities do not have the kind of university-industry partnership opportunities that abound in the U.S. (BERNASCONI, 2008).

Much like their North American counterparts, universities in Latin America were founded to serve as a public good through a commitment to study and solve social, economic and political problems. With this goal, the typical characteristics of the Latin American public university in the 1960s and 1970s were no tuition charges, self-governance through democratic proceedings involving faculty, students, alumni, and staff, full state funding for university operations, autonomy of university governance and academic freedom from political powers (BERNASCONI, 2008, p. 
33). This autonomy from politics allowed public universities to play a central role in "transforming society" as agents of social change.

The Latin American university model changed from the 1970s through the end of the $20^{\text {th }}$ century. External factors such as military dictatorships, economic crises, and neoliberal politics threatened the university's place in society as the autonomous, publicly funded, critical social conscience. During that time, Latin America moved from an elite access model (up to 15\% of 18-22 year-olds enrolled in higher education), to the massification stage (up to $35 \%$ ) or a universal access stage (more than $35 \%$ ) (AROCENA; SUTZ, 2005). The rapidity of the enrollment expansion placed a burden on institutions to increase programming and financially support a greater number of students. The expansion led to a deterioration of the quality of programs as well as a diversification of the kinds of programs and institutions (BERNASCONI, 2008). The growth of enrollment, expansion of extant institutions, and the creation of new institutions required increased state financial support, which, particularly in the middle of the inflation and political unrest of the late $20^{\text {th }}$ century, was not readily available. Out of necessity and with the encouragement of organizations like the World Bank, many Latin American universities initiated tuition charges for public university students, moving away from the traditional model of no tuition (BERNASCONI, 2008).

Globalization and international rankings put pressures on Latin American universities to adopt more capitalistic practices to increase their rankings. One of the challenges with the existing university ranking systems is that they are based on a narrow set of criteria that reinforce an Anglo-Saxon model of higher education above other alternatives (ORDORIKA; LLOYD, 2015). The traditionally free, public higher education model focused primarily on domestic economic and social development issues is not valued in a rankings formula that privilege research output and academic reputation (ORDORIKA; LLOYD, 2015).

Rankings have become an important part of higher education as universities use them to demonstrate their value and to influence potential students and their parents. An alternative to changing the traditional, free higher education system is to create new criteria for the rankings calculus. For instance, the Comparative Study of Mexican Universities (produced by the National Autonomous University of Mexico) provides information on 3,000 institutions through an interactive database, but deliberately does not assign institutional rankings (ORDORIKA; LLOYD, 2015). 
Dias and Serafim (2015, p. 335) identified three factors that affected Brazilian public universities since the 1990s: academic capitalism, innovation, and research productivity. These are reflected in the "fourth mission of the university", model 2 knowledge production, entrepreneurialism, obsession with rankings and the mercantilization of knowledge. Based on what they label the "neoliberal fable" of Reagan and Thatcher, Dias and Serafim indicated that little critical discussion has transpired of how these activities have influenced the social role of the Latin American university. They concluded that Brazilian universities should critically debate the role of the public university and prevent these institutions from becoming more than diploma, publication and patent mills.

Leite (2010, p. 228) suggested universities have responded to trends and mandates from the Global North by adopting the Guaraní tradition of anthropophagy:

\begin{abstract}
Instead of copying foreign ideas there is a tendency to create new ones and re-elaborate them with an anticipatory view and an accent of Global South localism. A critical mass and part of the political class adopts the neo-liberal [educational] policy initially, and then immediately afterwards it commits anthropophagy - it digests what it finds useful, regurgitates what does not concern it, and absorbs what will do some good.
\end{abstract}

The alternative of becoming caught up in the academic arms race for higher rankings through increased entrepreneurial activities can result in "underdeveloped universities" that shun their mission to provide a public good (RHOADES et al., 2004, p. 326). Instead of emulating academic capitalism, Rhoades and colleagues suggested an alternative strategy where universities might find success by emphasizing their strengths. They present the example of the largest private university in Mexico, the Instituto Tecnologico y de Estudios Superiores de Monterrey (ITESM), to demonstrate how a university has incorporated aspects of a western model with the traditional public service mission of Latin American universities. ITESM focuses on professional degrees and undergraduate education. It narrowed its mission by purposefully limiting involvement in research and doctoral programs. The anthropophagic strategy allows ITESM to maintain commitment to the community while meeting the standards for accreditation by the Southern Association of Colleges and Schools (SACS).

Brazilian higher education experienced an increase in academic capitalism in the 1990s with the increase of private for-profit institutions. These for-profit institutions were designed for workforce and technical training, moving higher 
education in Brazil towards a "knowledge factory" model centered on training “consumers" and providing an educational product (MARTINS, 2008, p. 736).

In contrast to the traditional free, public institutions dedicated to humanistic values and the diffusion of knowledge and academic research, these newer for-profit institutions provided professionalization and training for the growing technology industry in Brazil. The employment crisis of the 1990s placed additional pressure on higher education to produce graduates with skills for the workforce, reinforcing a model of academic capitalism in universities (MARTINS, 2008). The movement of higher education in Brazil towards academic capitalism should be met with caution (MARTINS, 2008), since such a transition results in a slow corrosion of the cultural role of universities in Brazil to serve the public good and the opportunities for students to obtain degrees at little to no cost.

McCowan (2017) described Brazilian higher education as having a high degree of classification, offering few interdisciplinary programs, and relying on the pedagogical strategy of lecture-based courses. These characteristics encourage the unbundling of services into smaller, more cost effective units. Some universities award "badges" for each unit that can be "stacked" to make certificates or a degree. This makes the educational "product" more accessible, attractive professionally, and affordable for employed adults who seek a degree to enhance their career prospects. Unbundling can range from outsourcing of services (such as janitorial, printing, parking, grading papers) to cut costs to developing online lectures by a superstar faculty member which are integrated into a course taught by an inexpensive graduate student in an effort to increase revenues. McCowan noted three threats of undbundling: the loss of connections between teaching and research, the undermining of education as a public good and issues with extended basic research projects with no quick financial return in terms of a patent.

Brazilian institutions can respond to the impending threats of academic capitalism in several ways. First, the strong traditions of academic autonomy, selfgovernance, and academic freedom should be maintained. This is in contrast to the erosion of self-governance and growth of intrusive management in the U.S. (BOWEN; TOBIN, 2015). Second, federal universities implemented changes to salary and retirement benefits that could discourage new Ph.D.s from pursuing an academic career; those perquisites should be restored. Third, industry-university partnerships should be collaborative, in contrast with the power differential that 
favors corporations in U.S. partnerships. Finally, faculty members and institutions should resist efforts designed to "free" faculty members from less productive student advising and teaching to focus on much more aggressive grant writing, fundraising, research and outreach activities.

\section{CONCLUSION: THE REAL IMPACT OF ACADEMIC CAPITALISM}

To conclude this article, we briefly discuss the academic arms race through the use of academic capitalism. The influences are both institutional and individual.

All higher education institutions do not have the same mission or context. Ordorika and Lloyd (2015) have likened the international rankings of universities to a "Harvard-ometer". Ironically, for some universities the only similarity to Harvard is that both have students, faculty and administrators. To use the same criteria to compare Harvard with intercultural universities in Mexico, online universities that provide outreach to less populated areas in Latin America, indigenous institutions, the multilateral University of Lusophone Afro-Brazilian International Integration (UNILAB) and University of Latin American Integration (UNILA), and Zumbi dos Palmares University is unfair and an extreme exercise in isomorphism. Yet, this is exactly the effect of international rankings.

Lost in all of the discussion about research productivity and industry collaboration is the philosophy of higher education as a public good equally accessible for poor, middle-class and wealthy students alike. In the U.S., first-generation and low-income college students are often served by regional universities, community colleges, Hispanic-Serving Institutions, Historically Black Colleges and Universities, and Tribal (Indigenous) Colleges. These institutions provide an important and vital service to students who might be under-served at Research Universities. Further, the "value added" for these students can exceed that of the intellectual and pecuniary gains for students at many elite universities.

Academic capitalism likewise has a profound impact on the faculty. Gonzales, Martinez, and Ordu (2014) talk of the "striving university" and the resulting strain on faculty members. A striving university is "prestige-seeking," reaching for increased prestige through fundraising, developing selective student admissions, recruiting and rewarding faculty members, making curricular changes, 
reallocating resources to favor research and the development of a public relations program ("branding”) (GONZALES; MARTINEZ; ORDU, 2014, p. 1099). The singular goal of the striving university is to advance in the rankings and increase institutional prestige.

A striving university, however, has a much more limited budget than a Research University. The result is dramatically increased expectations for the faculty with little support and infrastructure. The faculty members interviewed by Gonzales and colleagues talked about "being all things to everyone" (GONZALEZ; MARTINEZ; ORDU, p. 1105). In the striving university, faculty are required to teach 40 students per class, advise students, research, publish, write grant applications, develop an international reputation and other activities intended to help boost the university's rankings. With both new technologies and increased expectations, the faculty members have very fluid lines between their work life and family life: their challenge is to "outsmart time". Further, the focus is on publishing in highly selective journals and doing research that would generate revenue in the form of grants, contracts and patents. The result is that the aspirations of the striving university have affected faculty life for the worse.

Faculty members at striving universities also report increased surveillance of their work outcomes, including the imposition of many measures with which they disagree. Their accountability is only calculated in narrow quantitative terms, such as number of publications, impact factor for publications, grant dollars generated and the amount of revenue generated per faculty member. Some faculty members report the expected revenue generation is five times their annual salary per annum.

The unstoppable forces of decreased funding and increased expectations have required universities around the globe to turn to the philosophy of academic capitalism to produce a cheaper "educational product" and increase faculty research, fundraising and business/industry activities. In the United States, all of these expectations have created a dysfunctional climate for faculty members. However, Brazil, with its dual approach to higher education may have a different trajectory. The high-quality, free, federal university system stands poised to resist whole-scale academic capitalism. On the other hand, the private sector, with its monthly tuition charges that approach the national minimum wage, is very susceptible to putting profits over people. We recommended that all Brazilian faculty can commit anthropophagy, resisting the harmful parts of academic capitalism while modifying positive elements. 
This continues the strong tradition of autonomous public universities that serve the needs of students and community.

\section{REFERENCES}

\section{AMERICAN ASSOCIATION OF UNIVERSITY PROFESSORS. Busting} the Myths: the annual report of the economics status of the profession, 20142015. Washington, DC, 2014. Available from: < https:/www.aaup.org/reports-publications/2014-15salarysurvey>. Access on: Mar 3, 2018.

AROCENA, R.; SUTZ, J. Latin American universities: From an original revolution to an uncertain transition. Higher Education, v. 50, i. 4, p. 573-592, 2005.

ARUM, R.; ROSKA, J. Academically Adrift: limited learning on college campuses. Chicago, Illinois: University of Chicago Press, 2010.

BALTODANO, M. Neoliberalism and the demise of public education: The corporatization of schools of education. International Journal of Qualitative Studies in Education, v. 25, i. 4, p. 487-507, 2012.

BERNASCONI, A. Is there a Latin American model of the university? Comparative Education Review, v. 52, i. 1, p. 27-52, 2008.

BOK, D. Are huge presidential salaries bad for colleges? The Chronicle of Higher Education, Washington, DC, 2002.

BOWEN, W. G.; TOBIN, E. M. Locus of authority: the evolution of faculty roles in the governance of higher education. Princeton, New Jersey: Princeton University Press: ITHAKA, 2015.

CHACE, W. M. A tale of two provosts. Common Knowledge, v. 19, i. 2, p. 211216, 2013.

CHRISTENSEN, C.; EYRING, H. J. The innovative university: Changing the DNA of higher education. New York: John Wiley \& Sons, 2011.

COLLEGE BOARD. College Cost: FAQs. 2015. Available from: <https://bigfuture. collegeboard.org/pay-for-college/college-costs/college-costs-faqs $>$. Access on: Mar 22,2018 .

DIAS, R.: SERAFIM, M. Comentários sobre as transformações recentes na universidade pública brasileira. Avaliação, Campinas; Sorocaba, v. 20, n. 2, p. 335-351, jun. 2015. 
DONOGHUE, F. The last professors: the corporate university and the fate of the humanities. The Bronx, New York: Fordham University Press, 2008.

GERBER, L. G. The rise and decline of faculty governance: professionalization and the modern American university. Baltimore, Maryland: Johns Hopkins Press, 2014.

GINSBERG, B. The fall of the faculty: the rise of the all-administrative university and why it matters. Oxford: Oxford University Press, 2013.

GOLDSTEIN, E. The undoing of disruption. The Chronicle of Higher Education. Washington, DC, 2015.

GONZALES, L. D.; MARTINEZ, E.; ORDU, C. Exploring faculty experiences in a striving university through the lens of academic capitalism. Studies in Higher Education, v. 39, i. 7, p. 1097-1115, 2014.

GONZALES, L. D. Responding to mission creep: Faculty members as cosmopolitan agents. Higher Education, v. 64, i. 3, p. 337-353, 2012.

INTEGRATED POSTSECONDARY EDUCATION DATA SYSTEM. About. 2018. Available from: <https://nces.ed.gov/ipeds>. Access on: Mar. 18, 2018.

LEE, E.; SOMERS, P.; FRY, J. The evolution of the American research university and non-faculty professional work. Austin, Texas: Unpublished paper, 2016.

LEPORE, J. The disruption machine. The New Yorker, v. 23, p. 30-36, 2014.

LEITE, D. Brazilian higher education from a post-colonial perspective. Globalisation, Societies \& Education, v. 8, i. 2, p. 219-233, 2010.

LUIZ DE MIRANDA MARTINS, A. A marcha do “capitalismo universitário" no Brasil nos anos 1990. Avaliação, Campinas, v. 13, n. 3, p. 733-743, nov. 2008.

MCCOWAN, T. Higher education, unbundling, and the end of the university as we know it, Oxford Review of Education, v. 43, i. 6, p. 733-748 July, 2017.

ORDORIKA, I.; LLOYD, M. International rankings and the contest for university hegemony. Journal of Education Policy, v. 30, i. 3, p. 385-405, 2015.

PRIEST, D. M.; St. JOHN, E. P. (Ed.). Privatization and public universities. Bloomington, Indiana: Indiana University Press, 2006. 
RHOADES, G.; MALDONADO-MALDONADO, A.; ORDORIKA, I.; VELAZQUEZ, M. Imagining alternativas to global, corporate, new economy academic capitalism. Policy Futures in Education, v. 2, i. 2, p. 316-329, 2004.

SELINGO, J. J. College (un)bound: the future of education and what it means for students. Las Vegas, Nevada: Amazon Publishing, 2015.

SELINGO, J. J. Education innovators: Preaching (as usual) to the choir. The Chronicle of Higher Education, Washington, DC, 2012.

SLAUGHTER, S.; LESLIE, L. Academic capitalism: politics, policies, and the entrepreneurial university. Baltimore, Maryland: Johns Hopkins University Press, 1997.

SLAUGHTER, S.; RHOADES, G. Academic capitalism and the new economy: markets, state, and higher education. Baltimore, Maryland: Johns Hopkins University Press, 2009.

SLAUGHTER, S.; RHOADES, G. State and markets in higher education: trends in academic capitalism. In: BASTEDO, M. N.; ALTBACH, P. G.; GUMPORT, P. J. (Ed.). American higher education in the 21st century: social, political, and economic challenges. 4. ed. Baltimore, Maryland: John Hopkins University Press, 2016.

SNYDER, T. D.; DILLOW, S. A. Digest of Education Statistics 2010 (NCES 2011-015). Washington D. C.: Institute of Education Sciences: U.S. Department of Education, 2011.

SPELLINGS, M. A Test of Leadership: charting the future of U.S. higher education. Washington, DC: U.S. Department of Education, 2006.

WINSTON, G. College costs: Subsidies, intuition, and policy. Boston, Massachusetts, 1997. Paper presented at the National Commission on the Cost of Higher Education.

Recebido em: 07 de março de 2017

Aceito em: 03 de setembro de 2017

Endereço para correspondência: Austin, TX 78712, EUA; pasomers@austin.utexas.edu 
